\title{
Technical Study of Gilding Ornaments on Stony inscriptions in Vank Cathedral-Isfahan
}

\author{
Adele Mohtasham* \\ PhD candidate in conservation and restoration of cultural- historical objects, Art University, Tehran, IRAN
}

\begin{abstract}
Gilding on stone is a worthwhile ornaments. These ornaments are vulnerable because of their multilayer structure. This art has been used in the objects and architectural ornaments. Nowadays, a few of these ornaments has been identified. Perhaps this is related to vulnerability of gilding. In this research the technical characteristics of a sample of these decorations in Vank Cathedral belonging to the Safavid period has been studied. The aim of this research was the identification and registration of the technical properties of gilding ornaments on stony inscriptions in Vank Cathedral in Isfahan, where these architectural decorations has been neglected in Iran. The reviews and identifying examples of preIslamic Iranian art, proved popularity of these ornaments in pre-Islamic Iran. Moreover, examples of Islamic art-especially in the late era of Safavi, Zand and Qajar were identified. Laboratory study of a sample related to the Safavid period demonstrated the application of high-carat gold leaf with an oily substance as a binder. According to the studies conducted by the author, gilding on stone in Iran is done by four methods: 1) inlaying; 2) the use of gold foil; 3) the use of golf leaf; and finally 4) Pastiglia on stone. Historical Studies and review of written sources with comparison of the infrared spectrum of historical sample strengthened the probability of oil usage as a binder material. The techniques used in decoration of this inscription, was identified as "Leaf gilding"- "Oil-gilding". In this research, type of study has been library, on-site - observational and laboratory, and the method of amassing, has been citations to authentic documents, laboratory studies (wet chemistry and instrumental analysis), on-site observations and microscopic examination. Finally, with the analysis of the gathered data, the conclusion has been reached. The history and techniques of gilding have also been investigated during the study.

Keywords: Oil gilding, Gilding, SEM-EDS, FTIR, Ornaments on stone, Vank cathedral.
\end{abstract}

${ }^{*}$ Corresponding author: adele.mohtasham@yahoo.com 


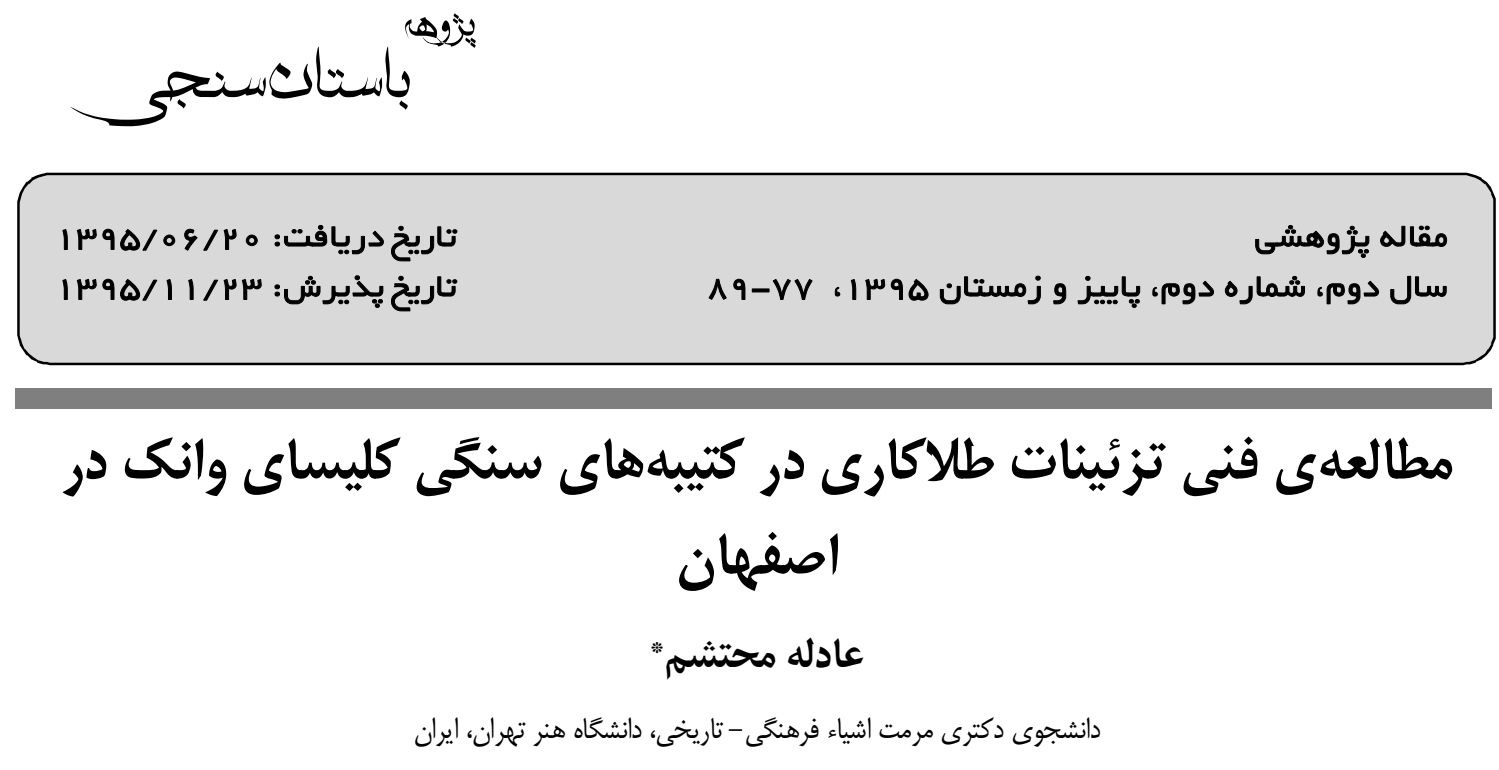

جִكيده

طلاكارى روى سنگ از جمله تزئينات ارزشمندى است كه به واسطهى ساختار لايهلايه و حساسش، در معرض آسيب و نابودى كامل

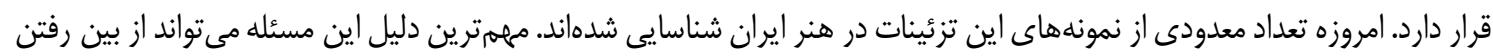

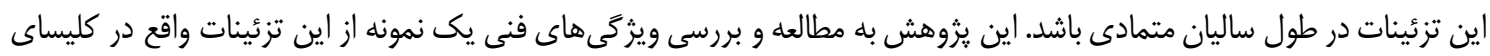

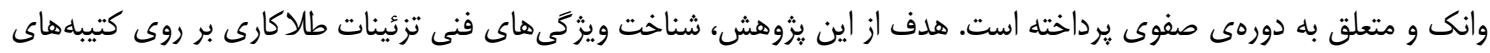

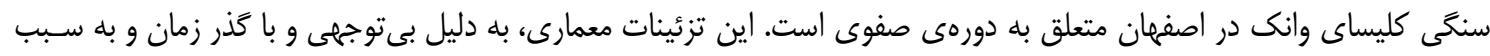

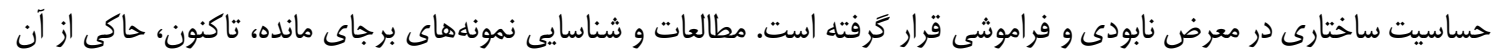

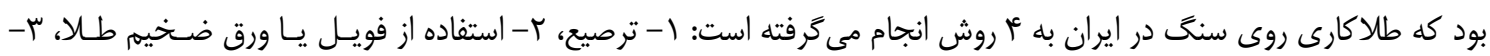

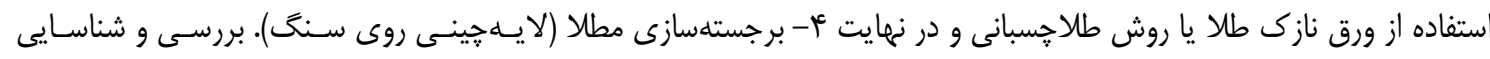

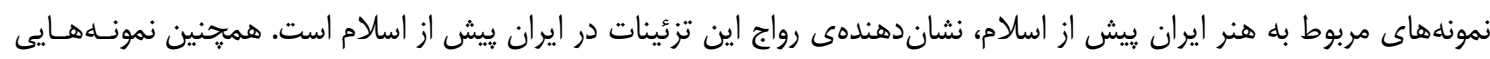

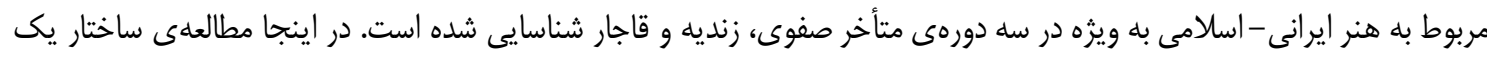

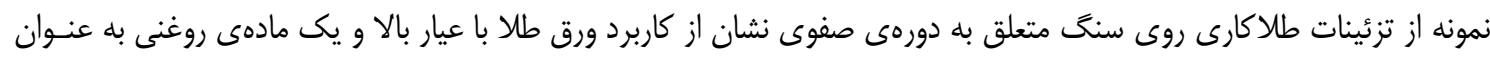

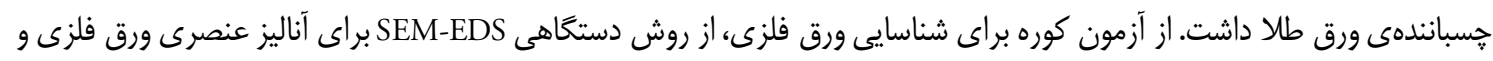

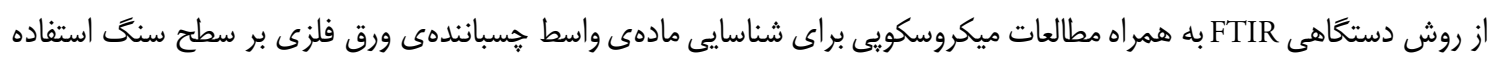

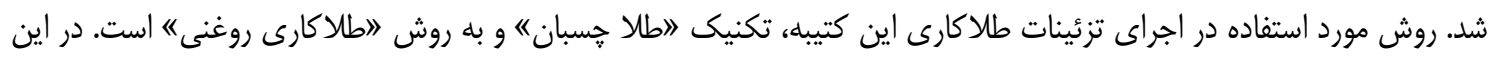

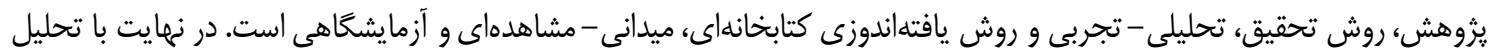

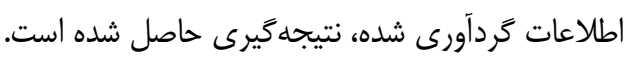

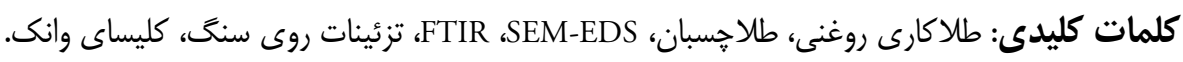

" مسئول مكاتبات: تهران، خيابان سى تير، خيابان سرهنگ سخايى، مجموعلى دانشكاه هنر

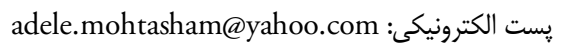
C) حق نشر متعلق به نويسنده(كان) است و نويسنده تحت مجوز Creative Commons Attribution License به مجله اجازه مىدهد مقاله خاب شده

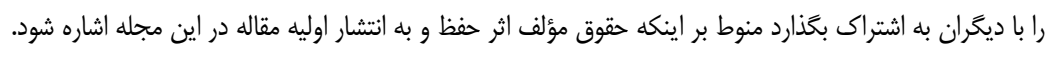


(طلا)، زرنكار، مطلا. آنجه ظاهرش با باطن فـرق داشـته باشد. همجنين است زرنغار: زينت داده شده و نقاشى شده

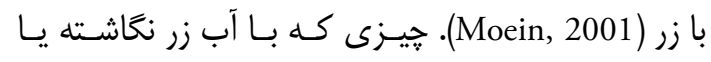

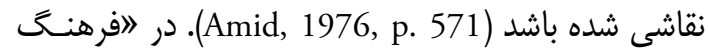

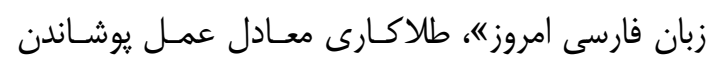

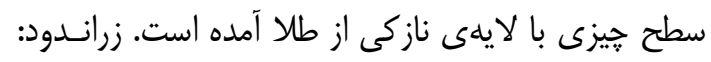

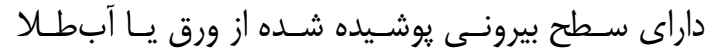
(Sadri Afshari et al., 1990, p. 661) (Goldplating)

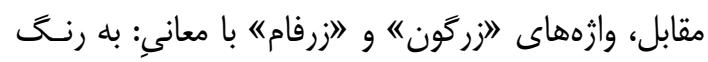
زر، مانند زر، طلائى و زردفام آمدهاند ) Amid, 1976, p. (571; Moein, 2001, p. 531

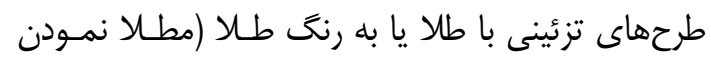

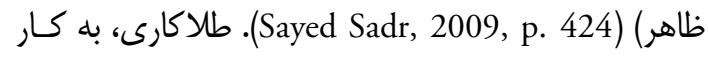

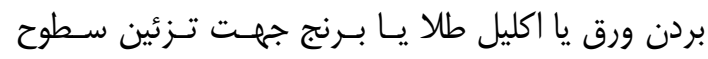

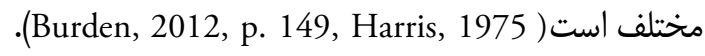

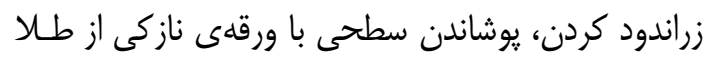

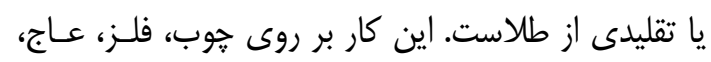

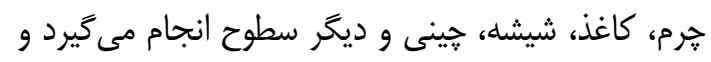

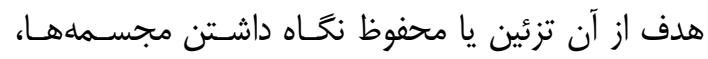

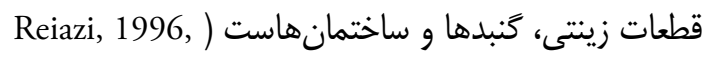
.). 76

تــا امـروز روشهــاى متعـدد مكــانيكى، فيزيكسى و و شيميايى جهت طلاكارى سطوح مختلف مورد استفاده قـرار كرفته است (Hatchfield \& Newman, 1991, p. 27-47).

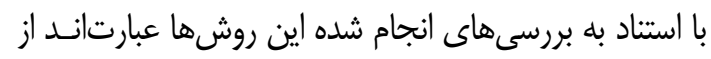

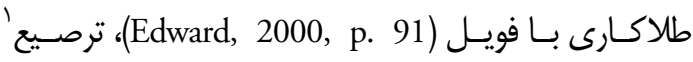
Habashi, 2005, p. ) با طلا، طلاكارى با ورق طلعا (Inlay)

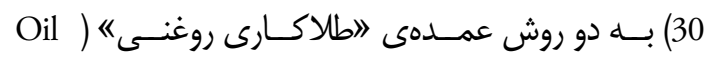
90 ) (Water gilding) (طلاكى "(gilding Gettens \& (Edward, 2000, p.

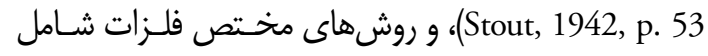

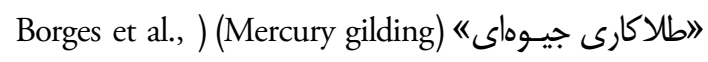

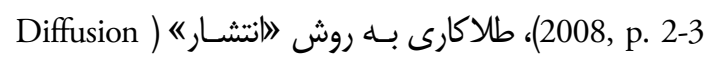

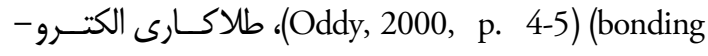
Lins, 2000, p. ) (Electrochemical gilding) شيميايس

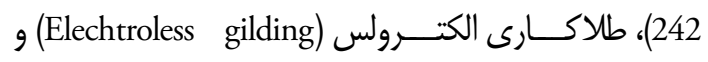
Oddy, ) (Elechtrolytic gilding) طلاكــارى الكتروليتى (242،
باستانسنجمـ

مقدمه

طلاكارى، هنرى گرَانمايه و بيش از هر جيز برخاسـته از

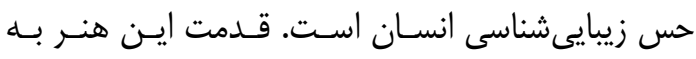

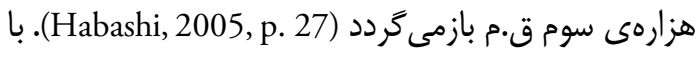

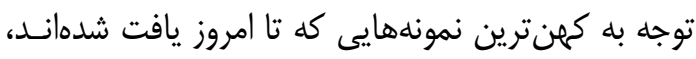

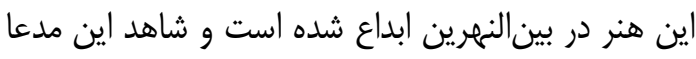

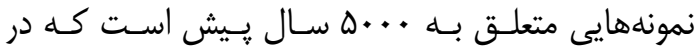

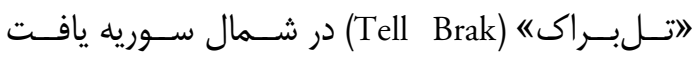

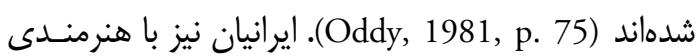

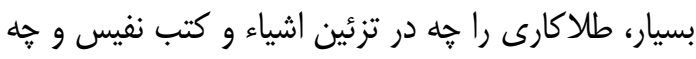
در تزئينات معمارى به كار بردهاند. در هنر ايران اين فن رأراء

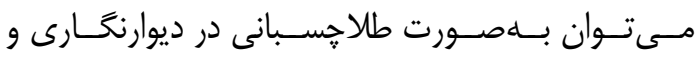
كتابآرايى، لايهجينى و طلاكارى بر روى انواع تكيه كاهها همجاتون شيشه و خوب مشاهده نمود. اما در ايـن ميـان،

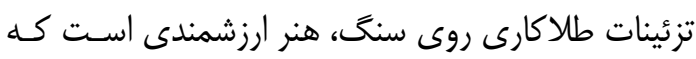

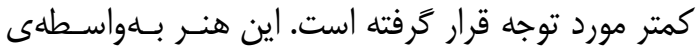
ساختار لايهلايه و تفاوت ماهوى مواد و مصالح آن، بسيار

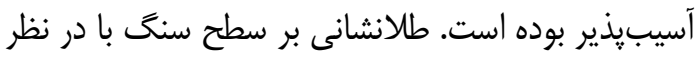

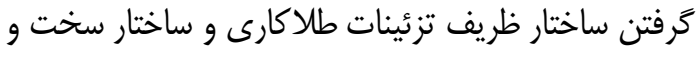

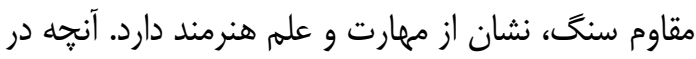

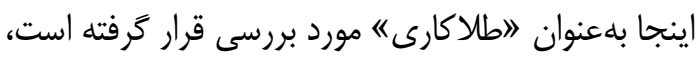

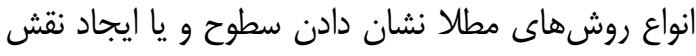

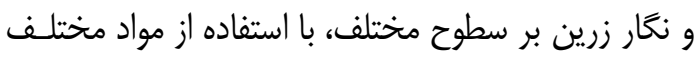

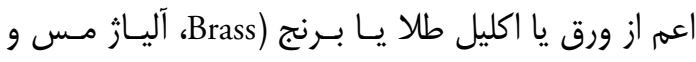

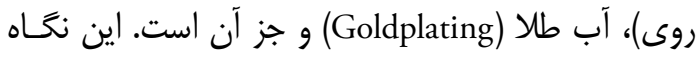

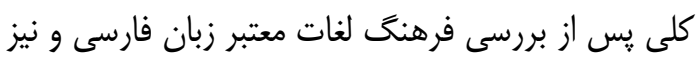
دايرهالمعارفهاى هنر حاصل شد. طلاكارى: عمل طلات طلاكار

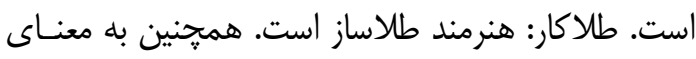

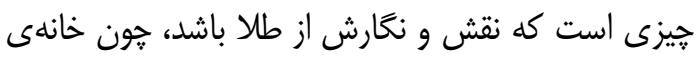

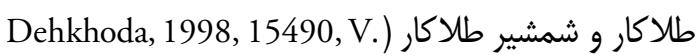

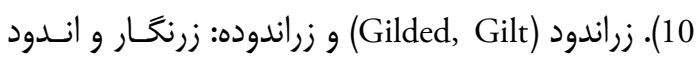

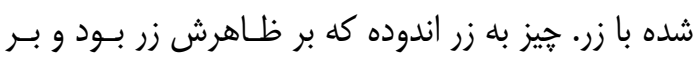

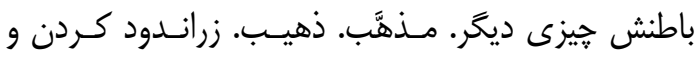

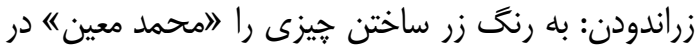

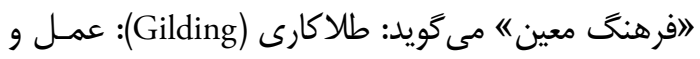

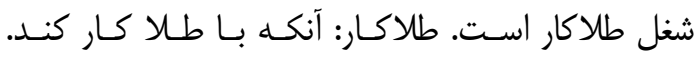

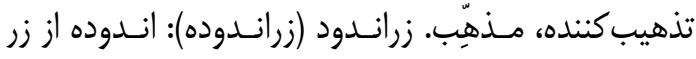

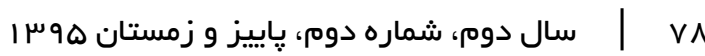


اجراى تزئينات طلاكارى روى سنگ مربـوط بـه دورهى

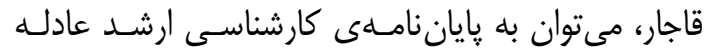

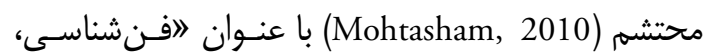
آسيبشناسى و طرح حفظ و مرمـت تزئينـات طلاكـارى

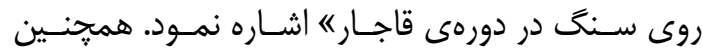
مى توان به مطالعلى موردى بر روى نمونههاى قاجـارى

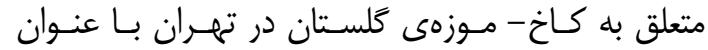
الفنشناسى تزئينات طلاكارى روى سنى در مجموعائى كاخ كلستان تهرانه اشاره نمود ( Ahmadi et al., 2011

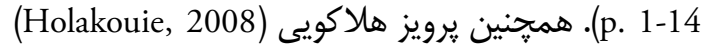

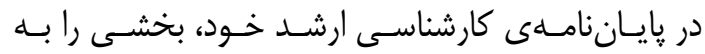

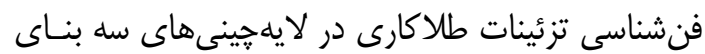
صفوى در اصفهان، اختصـاص داده اسـت. همجنـين در

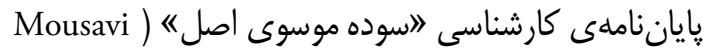

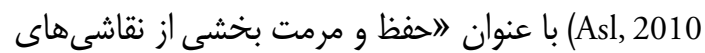

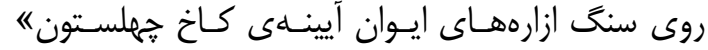

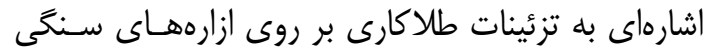

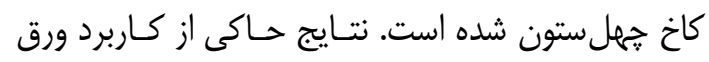

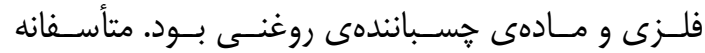

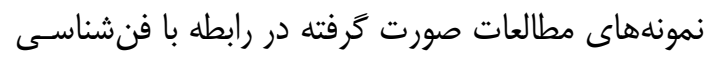

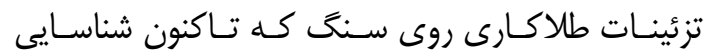

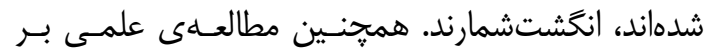

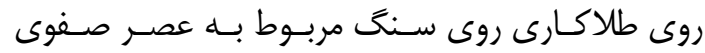

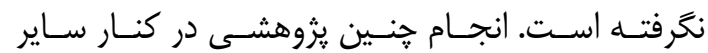
مطالعات در باب تزئينات طلاكارى روى سنَ در ديخـر

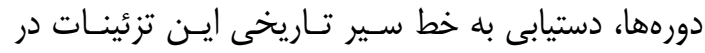

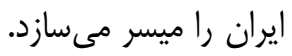

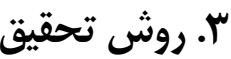

در اين يزوهش، روش تحقيق، تحليلى - تجربسى و روش

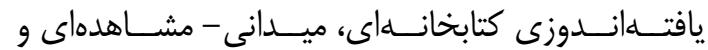

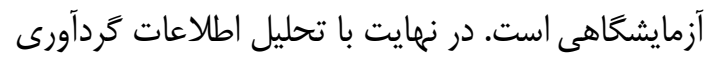
شده، نتيجه ئيرى حاصل شده است. از تست كوره بـراى ناى شناسايى ورق فلـزى، از روش دسـتخاهى ميكروسـكوب

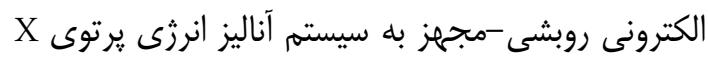

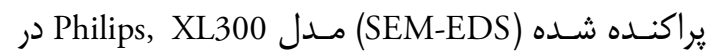
بخش آزمايشـاه دانشـحاه تربيـت مــدرس بـــاى آنـاليز
.(2000, p. 7-9

در ايران طلاكارى بر سطوح مختلف اجرا شده است.

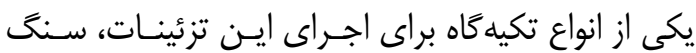
است. تعداد نمونههاى برجاىمانده از ايـن تـزئين بسـيار

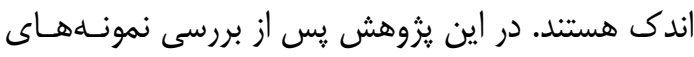

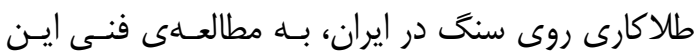
تزئينات در كتيبههاى سنگى كليساى وانـك در اصـفهان يرداخته مىشود. هدف از اين يزوهش، شناسايى، معرفى و ثبت نمونهها و ويزگكىهاى فنى نوعى از تزئينات معمارى

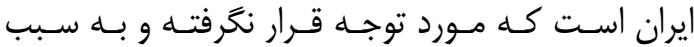
حساسيت ساختارى در معرض نابودى و فراموشى است.

\section{r. بيشينه تحقيق}

در زمينهى بررسى تاريخى تزئينات طلاكارى روى سنگ در ايران و نيز مطالعات فنى اين تزئينات در عصر صفوى ترئين تاكنون بررسى و يزووهشى صورت نكرفته است. همجنين

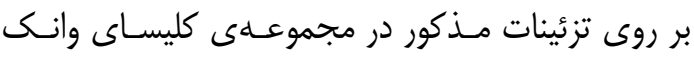
بررسى و مطالعهاى انجام نشده است. در رابطه با مطالعات تاريخى و بررسى بيشينهى كليساى وانكى مسىتـوان بــهـ

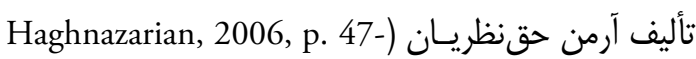

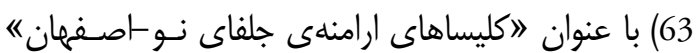
اشاره نمود. در زمينهى فنشناسى اين تزئينـات در سـاير

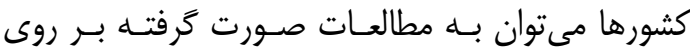
تزئينات ايوانهاى كليساى سويل (Sevil) در كشور اسِانيا اشاره نمود. نتايج اين تحقيقات حاكى از كاربرد ورق طلا و ورق قلع بر روى يك لايهى تداركاتى مركب از سـرنج

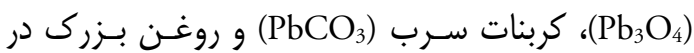
اجراى اين تزئينات بر تكيه كاه سنگى بود ( Duran, 2008

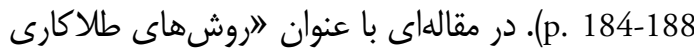

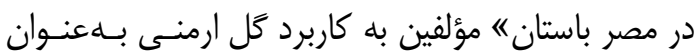
زمينهاى براى طلاجسبانى بر سطح مجسمههاى سـنَى Hatchfield \& Newman, 1991, p. 27-) اشاره مى كنيند

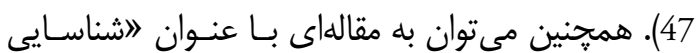

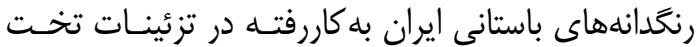
جمشيد و ياسار كاده اشاره نمود كه در آن مؤلف، به كاربرد ورق طلا بر سطح سنگ در تخت جمشيد يرداخته اسـت

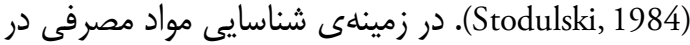

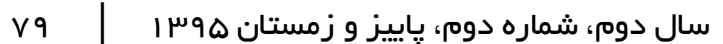


سوى جنوب حياط است... فضاى آن با رديف ستونهـاى مرمر به بَ دالان تقسيهم شده است... سمت قبله يـا مكـهـ

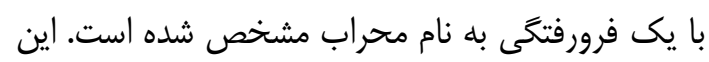
محراب زركوبى شده... سرستونها نيز با زر يوشيده شـده

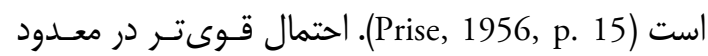

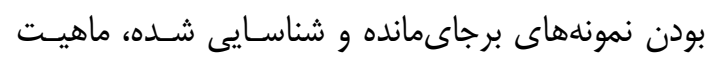

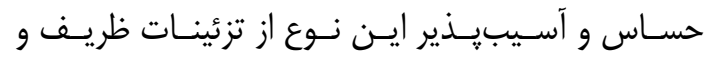

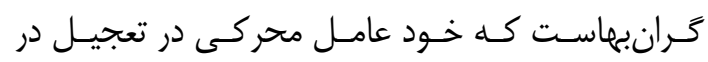

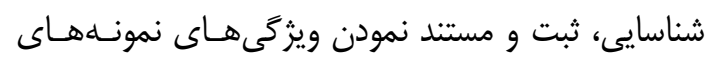

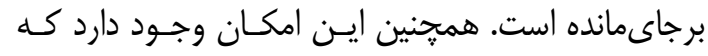

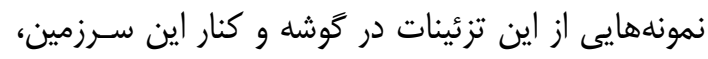

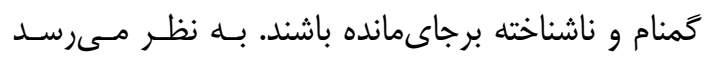

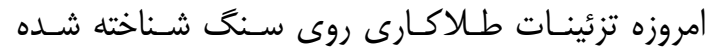

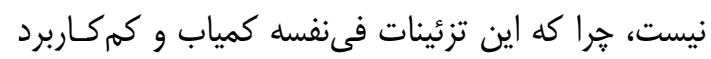

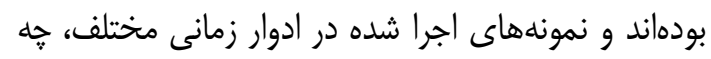

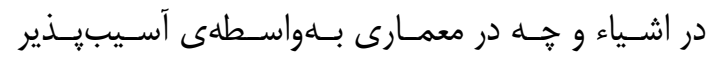

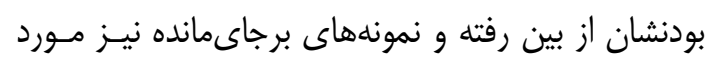

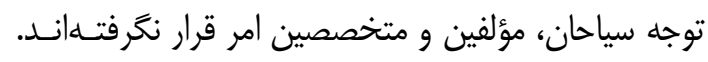

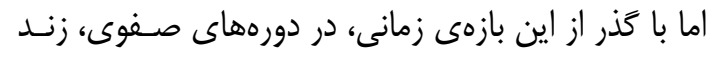

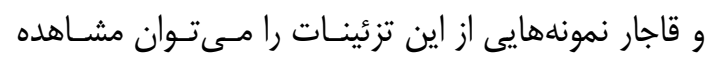

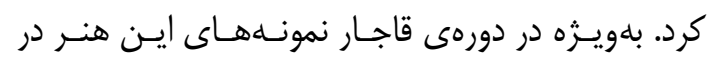

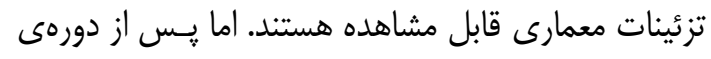

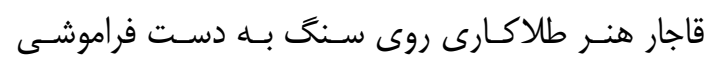

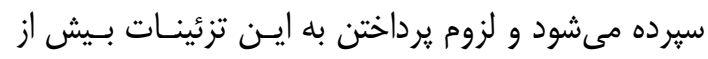

$$
\text { يبش احساس مىشود. }
$$

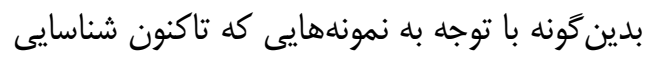

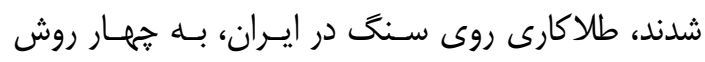

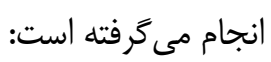

طلاكارى با استفاده از ورق ضخئه طات طلا (فويل)

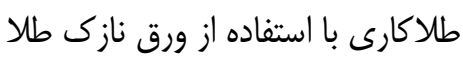
ترصيع برجستهسازى مطلا (طلاكـارى بـر روى زيرسـازى برجسته) يا لايهجينى إئل لازم به ذكر است روش طلاكارى با استفاده از يودر و يا رنحَدانهى طلا نيز مىتواند از روشهاى مور مورد استفاده در تزئين سطوح سنگى بوده باشد، اما از آنجايى كه هنئين نمونهاى مشاهده نشد، از ذكر آن خوددارى گرديد.
عنصرى ورق فلزى و از روش دسـتخاهى طيـفسـنجى

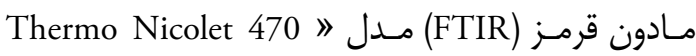
هexus

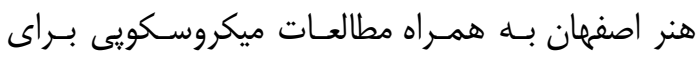

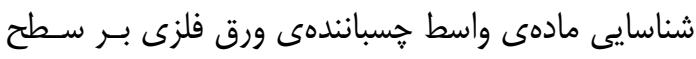

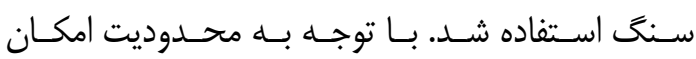

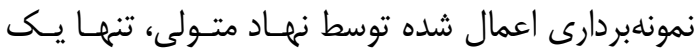
نمونه از توشهى سمت راست و وايين يكى از كتيبهـهـا

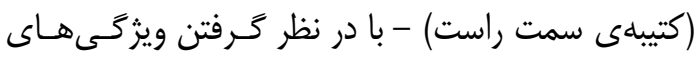
بصرى كتيبه -برداشته شد.

\section{f. نَّاهى به طلاكارى روى سنَ در ايران}

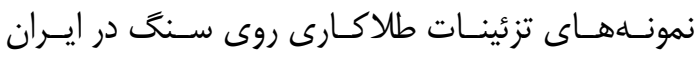

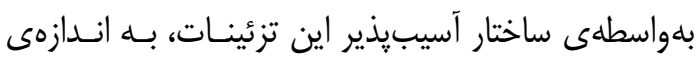

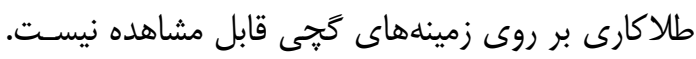
همجنين مىتوان استنباط نمود اين تزئينات اساساً كاربرد

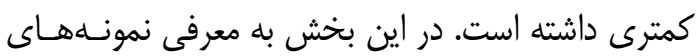

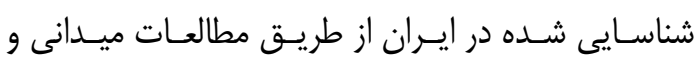
كتابخانهاى يرداخته شده است. با شناسايى اين نمونهانهـا،

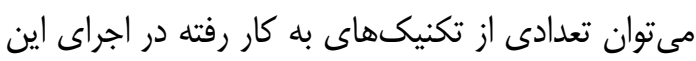

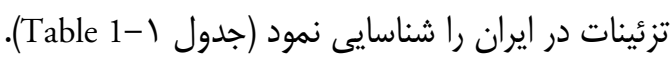

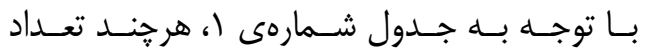
نمونههاى شناسايى شده در هنر يِيش از اسلام در ايـران إنهان

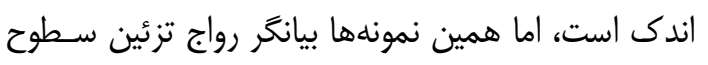

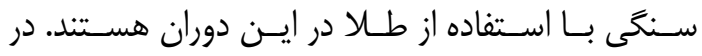

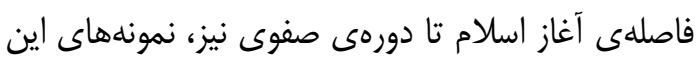

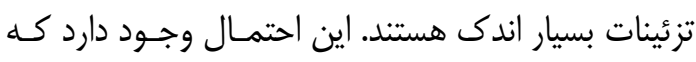
طلاكارى روى سنى در اين فاصلهى زمانى رايج نبوده و

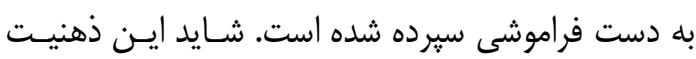
ايجاد شود كه بلواسطهى دستورات دين اسلام مبنى بـر

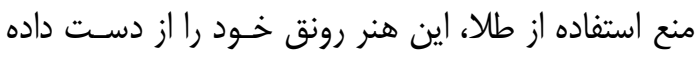

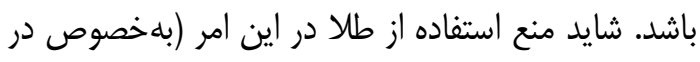

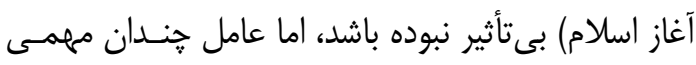

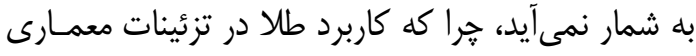

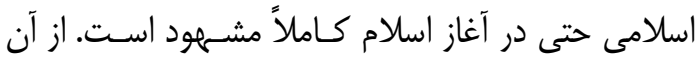

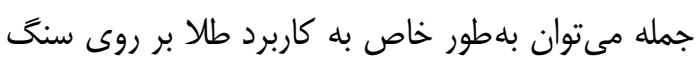

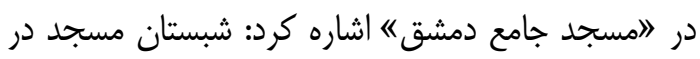

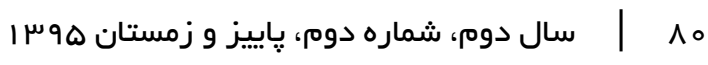


جدول (: نمونهاى شناسايى شده از تزئين طالاكارى بر روى سنگ در ايران (در مورد نمونهاى ستارمدار، بررسىهاى ميكروسكويى صورت گرفته

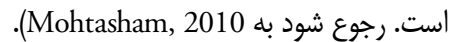

Table 1. Identified samples of gilding ornaments on stone in Iran.

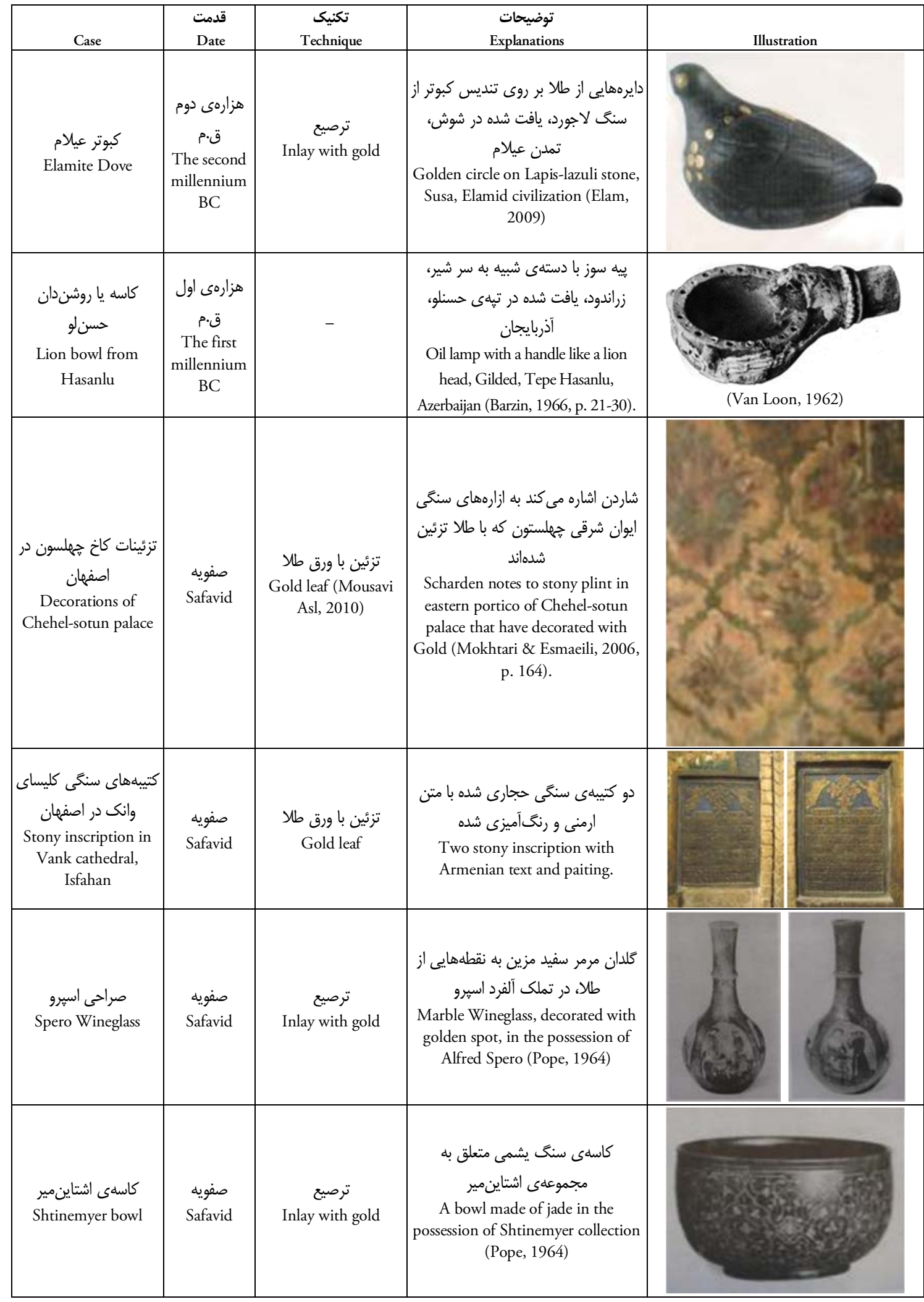

ادامه جلدول در صفحه بعد

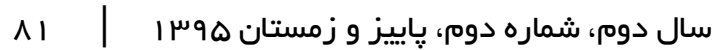




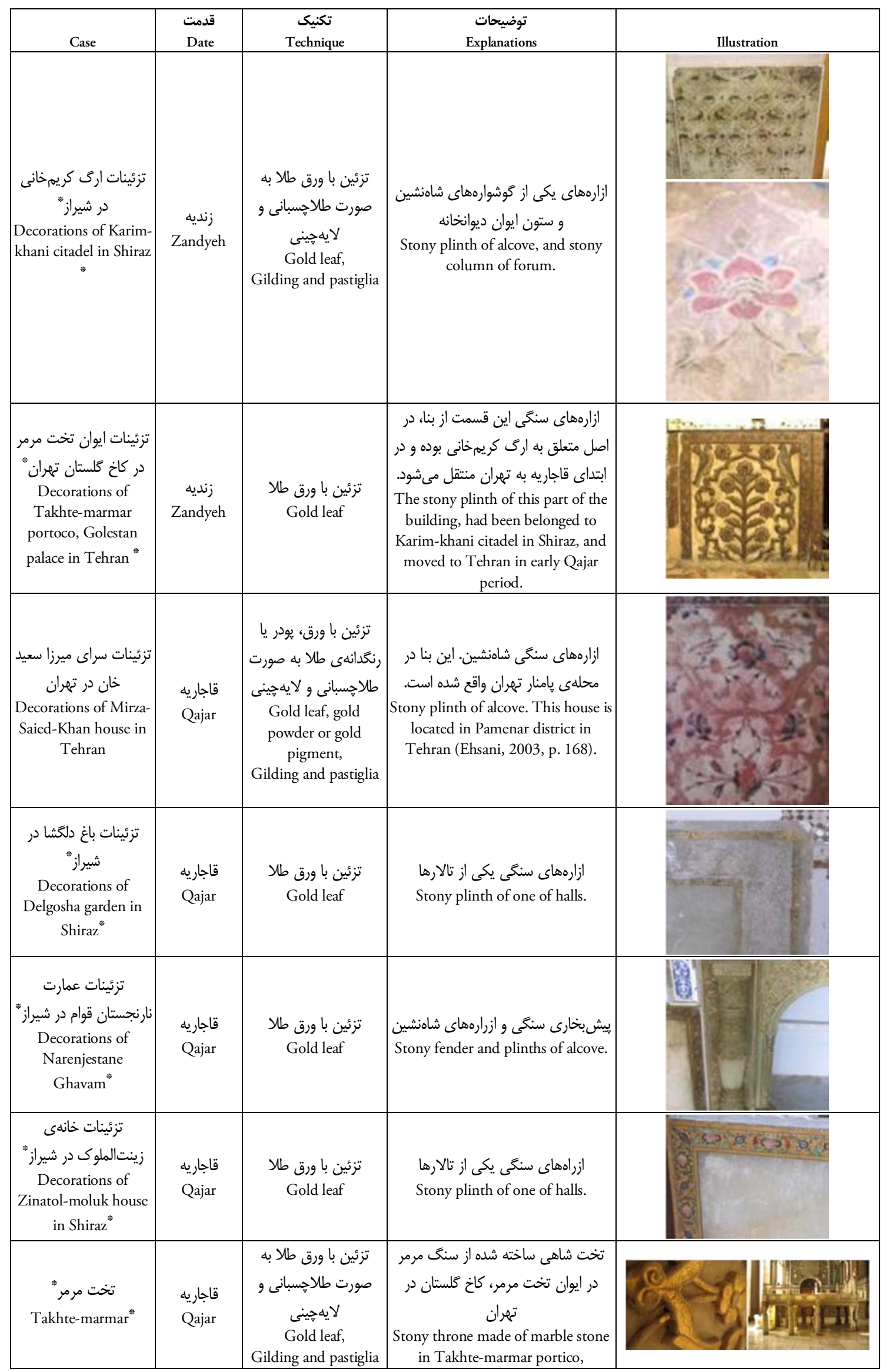




\begin{tabular}{|c|c|c|c|c|}
\hline Case & قدمت & $\begin{array}{c}\text { تكنيك } \\
\text { Technique }\end{array}$ & $\begin{array}{c}\text { توضيحات } \\
\text { Explanations }\end{array}$ & Illustration \\
\hline & & & Golestan palace, Tehran. & \\
\hline $\begin{array}{c}\text { تزئينات گوشوارهى غربى ايوان تخت مرمر" } \\
\text { Decorations of } \\
\text { western earing, } \\
\text { Takhte marmar } \\
\text { portico }\end{array}$ & قاجاريه & 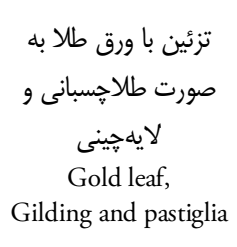 & $\begin{array}{c}\text { كاخ كلستان در تهران } \\
\text { Golestan palace in Tehran. }\end{array}$ & \\
\hline $\begin{array}{c}\text { سرى فتحعلى شاهى } \\
\text { Fath-Ali Schah } \\
\text { throne" }\end{array}$ & قاجاريه & $\begin{array}{c}\text { تزئين با ورق طلا } \\
\text { Gold leaf }\end{array}$ & 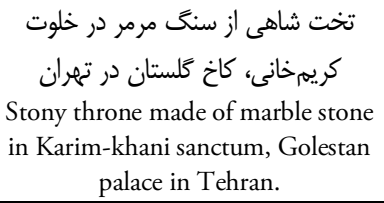 & \\
\hline $\begin{array}{c}\text { شزئينات كاخ العماره" } \\
\text { Decorations of } \\
\text { Shams-al-emreh } \\
\text { edifice" }\end{array}$ & قاجاريه & 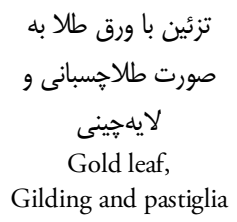 & $\begin{array}{c}\text { واقع در كاخ كلستان تهران، ازارههاى تالارهاى طبقهى اول و ايوان } \\
\text { Stony plinth of halls of first floor } \\
\text { and portico, Golestan palace in } \\
\text { Tehran. }\end{array}$ & \\
\hline $\begin{array}{c}\text { تزئينات عمارت بادگير } \\
\text { Decorations of Badgir } \\
\text { edifice }^{*}\end{array}$ & قاجاريه & $\begin{array}{c}\text { تزئين با ورق طلا } \\
\text { Gold leaf }\end{array}$ & $\begin{array}{c}\text { واقع در كاخ گلستان تهران، ازارههاى } \\
\text { Stony plinth, Golestan palace in } \\
\text { Tehran. }\end{array}$ & \\
\hline 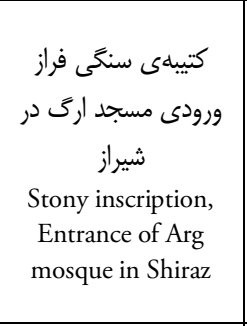 & قاجاريه & 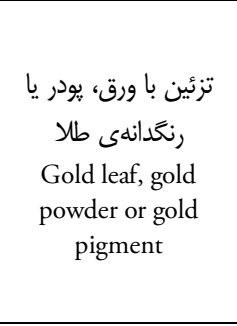 & 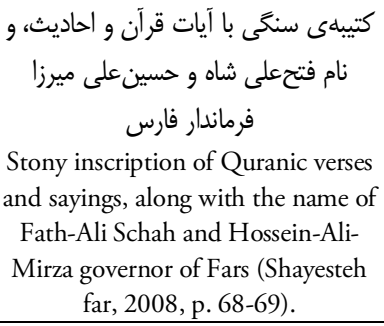 & \\
\hline $\begin{array}{l}\text { كتيبهى فتحعلى شاه در } \\
\text { Inscription of Fath-Ali } \\
\text { Schah in Taqe Bostan }\end{array}$ & قاجاريه & $\begin{array}{c}\text { تزئين با ورق طلاق } \\
\text { Gold leaf (Faraj } \\
\text { zadeh, 2011) }\end{array}$ & $\begin{array}{l}\text { طلاكارى بر روى تزئينات لباسها، سرير، } 1 \text { ساج وشير شخصيت اصلى } \\
\text { Gilding on ornaments of clothes, } \\
\text { throne, crown and sword of main } \\
\text { character. }\end{array}$ & \\
\hline
\end{tabular}

(Haghnazarian, 2006). اين بنا در عهد شاهعباس صفوى دئ ساخته شده و ديوارنخارههاى آن از شهمرت بسـيار برخهوردار

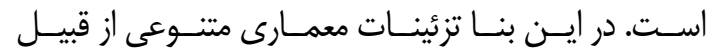
ديوارنغارى، كاشى كارى و لايهجينسى را مسىتـوان مشـاهده

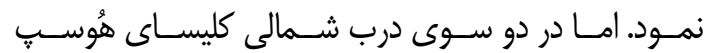

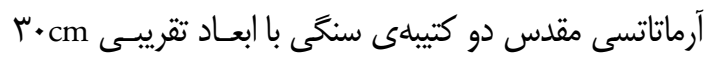

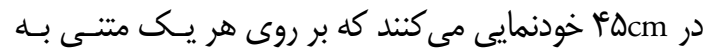

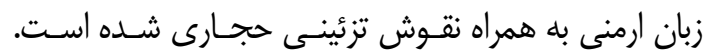

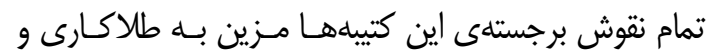

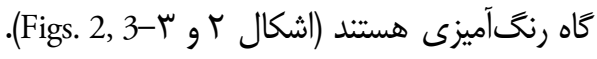

\section{ه. مطالعهى فنى تزئينات طلاكارى در كتيبههاى سنغَى كليساى وانك فئس}

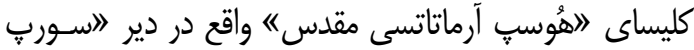

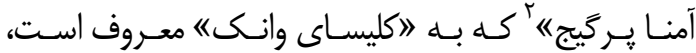

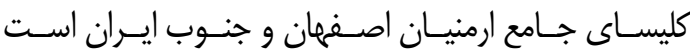

.(Caliphate of Isfahan \& west Iran Armenians, 2012) اين بنا يكى از زيباترين كليساهاى ارامنهى ايـران اسـت كـهـ

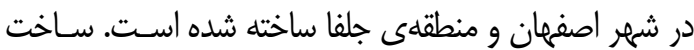

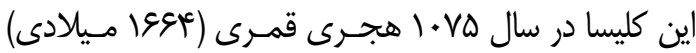

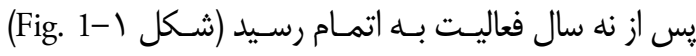




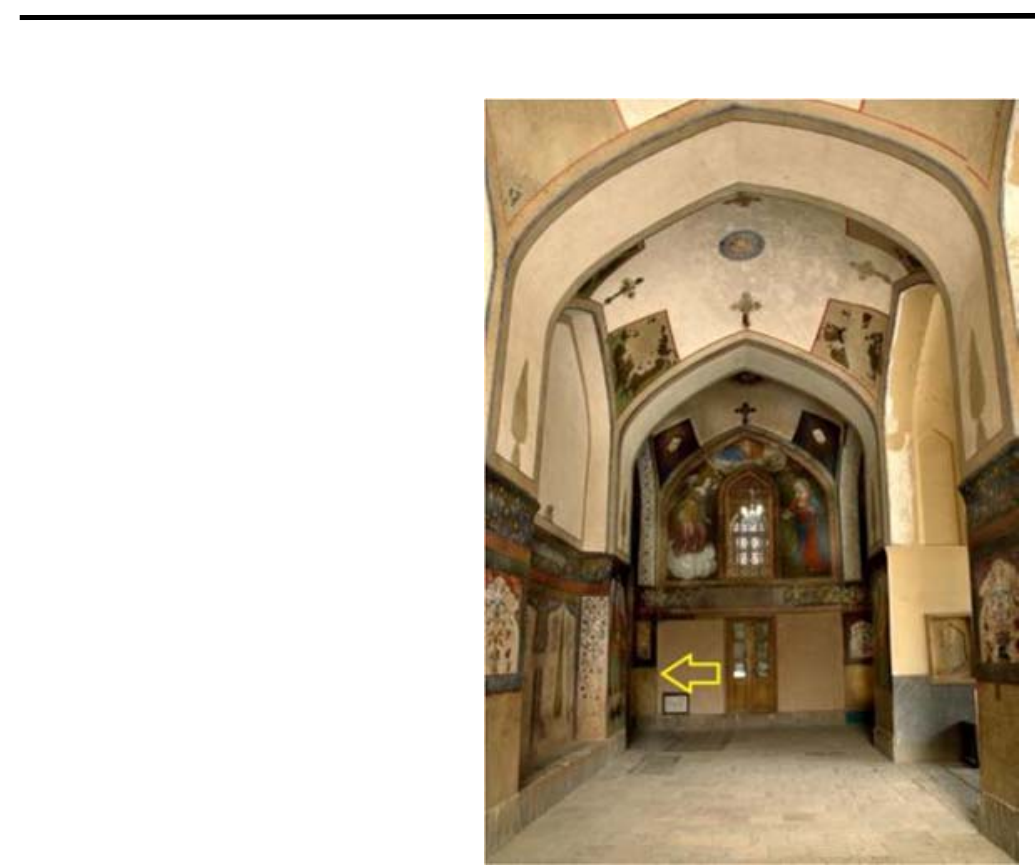

شكل ا: يكى از رواقهاى كليساى وانى كه دو كتيبهى سنكى در آن واقع شده است. محل قرارگيرى درب ورودى و كتيبههاى طلاكارى و

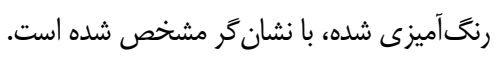

Fig. 1: The location of two gilded stony inscriptions in north portico-Vank Cathedral (Amena Pergij monastery, 2012).

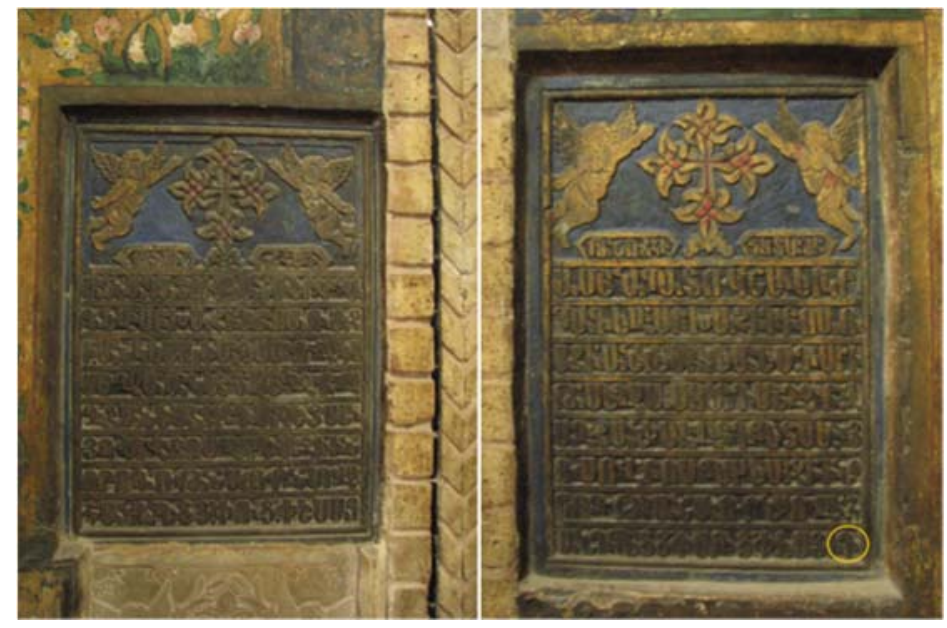

شكل ץ: كتبيههاى سنگى مطلا و رنگَآميزى شده در دو سوى درب شمالى كليساى هُوسب آرماتاتسى. محل نمونهبردارى با دايرهى زرد رنغ در

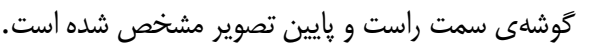

Fig. 2: Painted and gilded stony inscriptions- Northern gate of Hovsep Ārmātātsy church. Sampling location is marked with a yellow circle in the lower right corner.

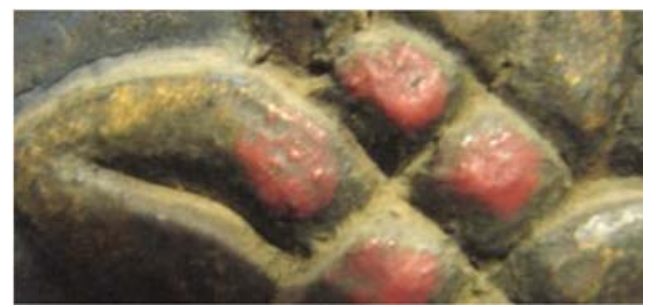

شكل سا: تصوير با بزر كنمايى از كتيبهى سنگى مذكور. تزئينات طلاكارى و رنگَآميزى در زير لايهاى از آلودگى قابل مشاهده است.

Fig. 3: Details of a stony inscription. Gilding and painting ornaments is visible under a layer of pollution.

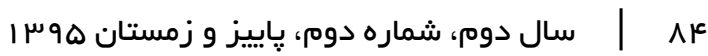



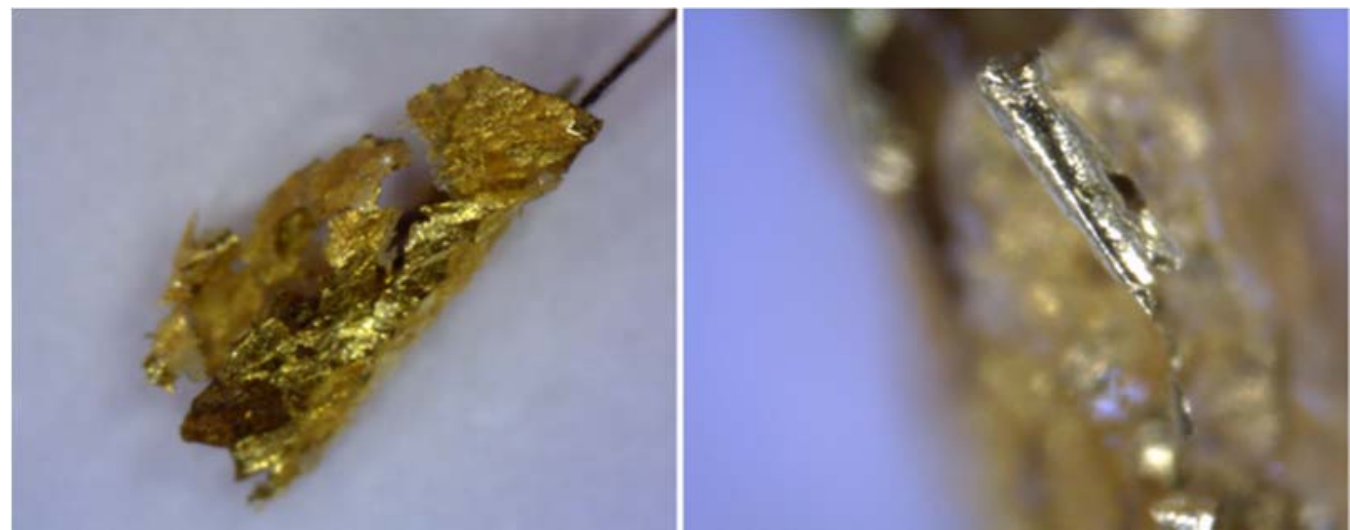

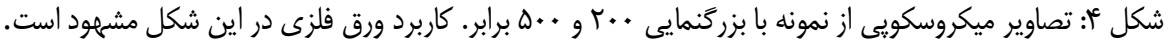

Fig. 4: Microscopic images of sample. Magnification: 200X and 500Xtimes. Use of metal leaf is evident in this figure.

فلزى بر سطح سنگ استفاده شد.

در تفسير طيف به دست آمده بايسـ كفــت بانسدهاى

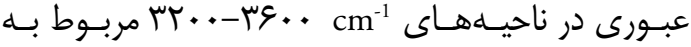
اتصالات O-H (خروه هيدروكسيل)، نشان دهندهى اتصالات C-H (كروه متين)، IVD + cm (كرون

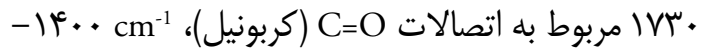

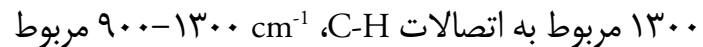

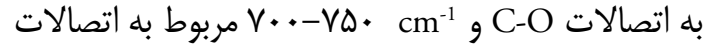
م- C-H

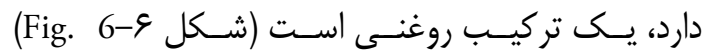
(Derrick, 1999, p. 95 \& 185) نمونهى مورد بررسى بيكهاى اين نـواحى را دارا اسـت. لازم به ذكر است مقدار نمونه، كم بوده است. نتايج اين آزمايش نشان داد كه از يك مادهى روغنى لمعنى
به جهت شناسايى مواد مصرفى در اجـراى تزئينـات طلاكارى در اين كتيبههـا، نمونسهبـردارى بسـيار جزئسى صورت گرفت به نحوى كه منظر كتيبه مخدوش نشـود. در ابتدا لازم بود كه مشاهدات ميكروسكويى قبـل از هـر

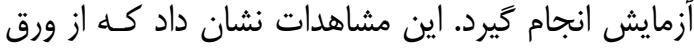

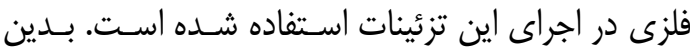

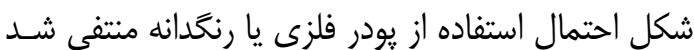
(شكل عig.4). (Fig). همجنين از يك مادهى واسط به جهت جسباندن ورق فلزى بر سطح سـنَّ اسـتفاده شــده كـــ

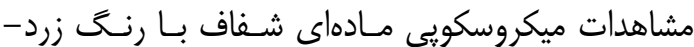
نارنجى را نشان داد (شكل ه-5ig. Fig). اين ماده در حسال حاضر شيشهاى و سخت است.

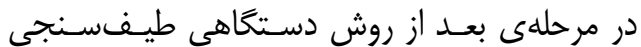
مادون قرمز FTIR براى شناسايى واسط خسبانندهى ورق
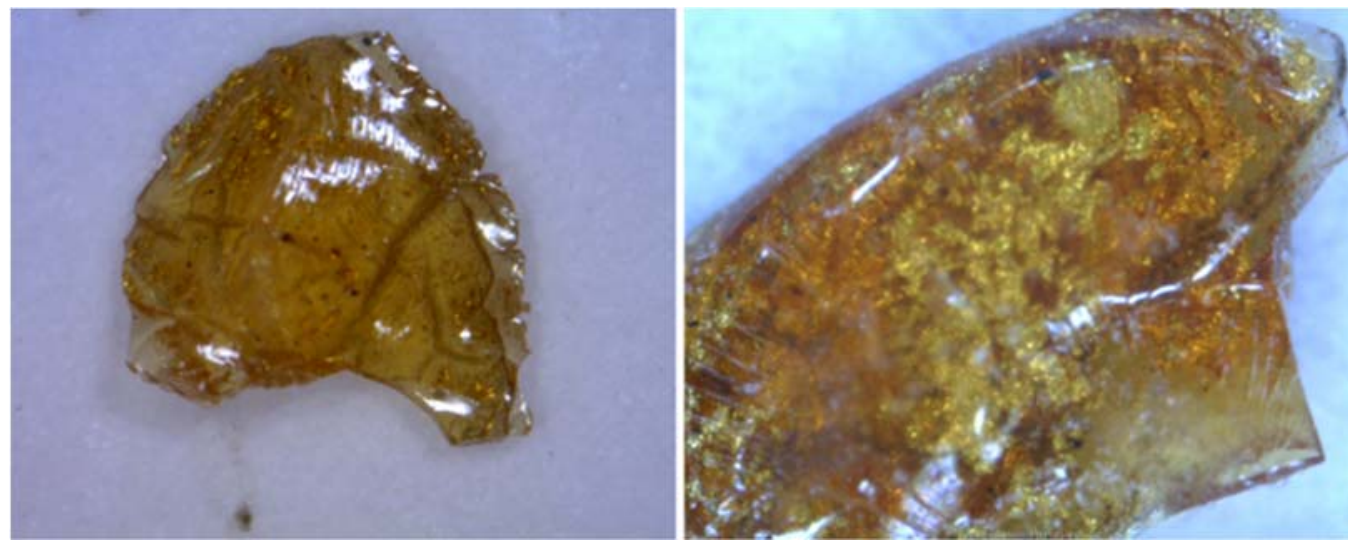

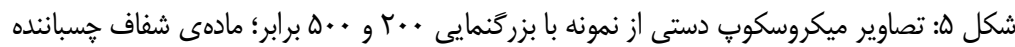

Fig. 5: Microscopic images of sample. Magnification: 200X and 500Xtimes, Transparent binder material 


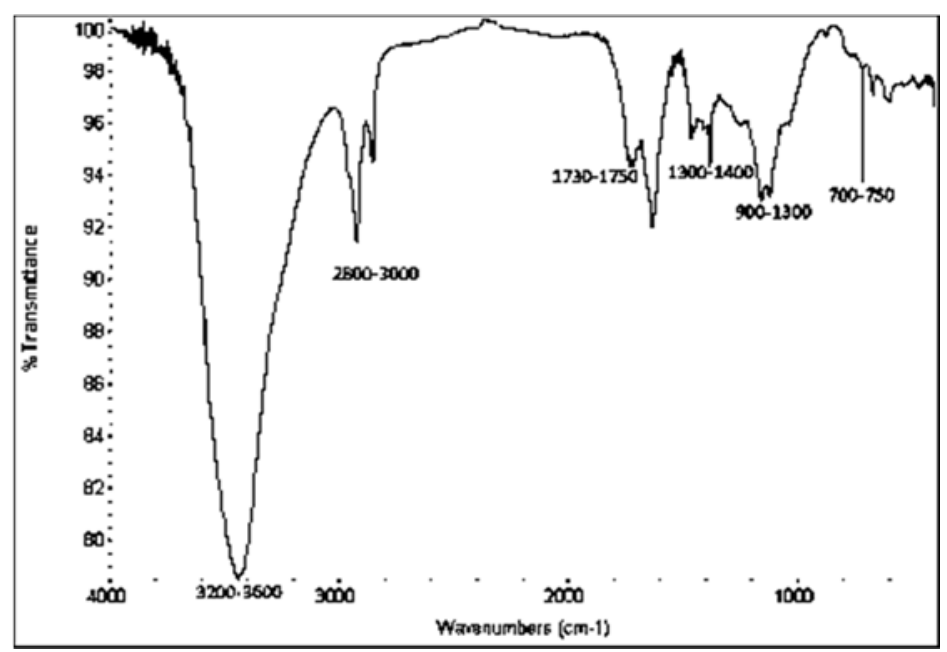

شكل و: طيف FTIR از مادهى جِبانندهى ورق طلا در طلاجِبان كتيبهى سنگى كليساى وانك

Fig. 6: FTIR spectrum of binder of gold leaf in Stony inscription-Vank Cathedral

رنغ نمونه و تيره شدن آن، احتمال كاربرد طلال منتفى مىشد (شكل V-7ig. (Fig).

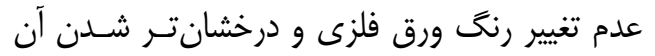
درنتيجهى تست كوره، احتمال استفاده از طلا با عيار بالا

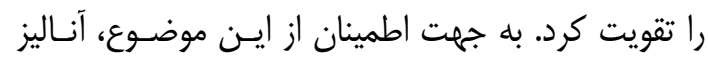

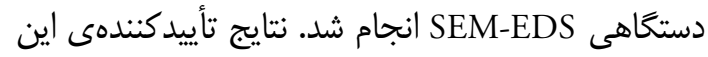

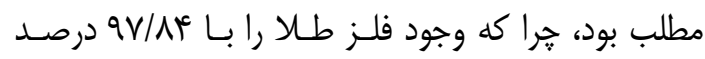

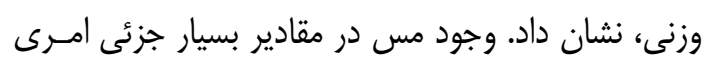
طبيعى بود. كلسيه با مقادير اندك، به تكيـهــاه سـنَّى

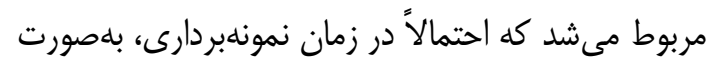

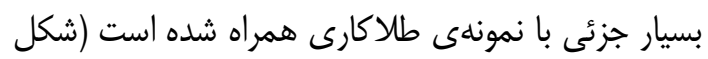

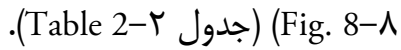

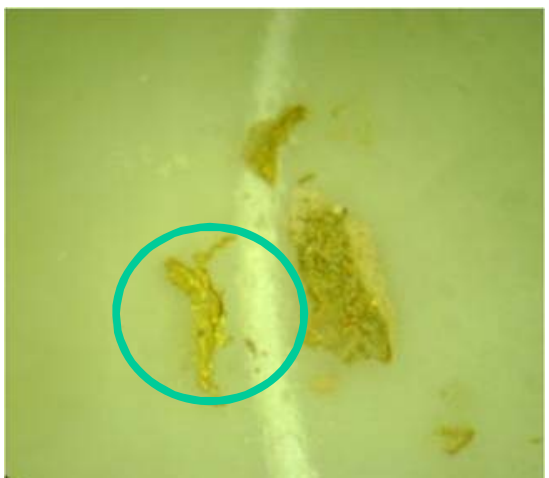

شكل V: تصوير ميكروسكويى نمونهى برجاى مانده از ورق طلا پِ زيس

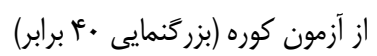

Fig. 7: microscopic image of remaining sample of gold leaf after furnace test (zooming eyepiece 40)
بدين منظور استفاده شده است. شناسايى نوع روغن بـهاطور

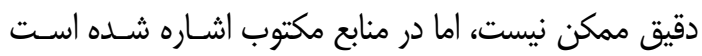
كه از "روغن كمان" در طاجِسبانى، در تزئينات معمـارى و

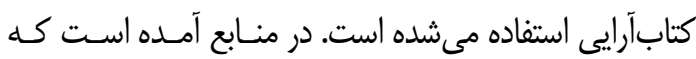

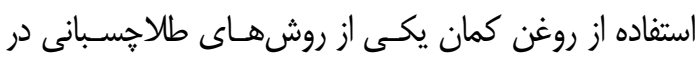

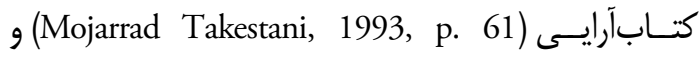

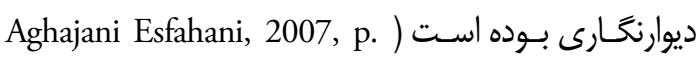
127). روغن كمان يوششى مرسوم و شناخته شده در ايـران

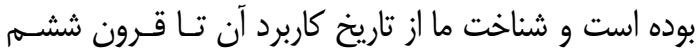
هجرى قمـرى بـازمى 2016, p. 1

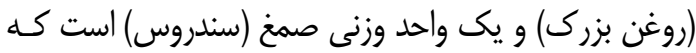

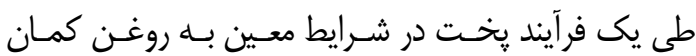
تبـديل مسىشـود (Monshi Qomi, 2013, p. 163-164).

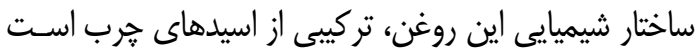
شامل: سندراكوليك اسيد، كاليتروليك اسيد، لينولنيك اسـيد،

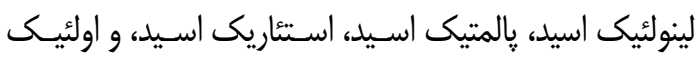

اسيد (Nemati Babaylou et al., 2013, p. 153). در ادامه لازم بود ورق طلايى رنح مورد بررسى قرار

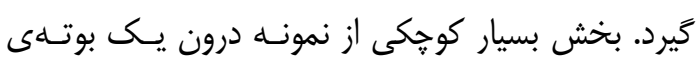

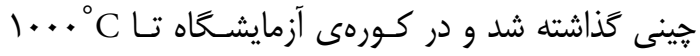

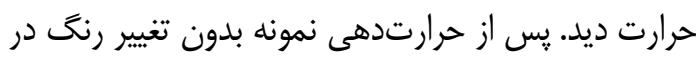

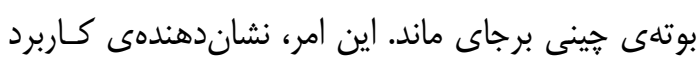
طلا (Au) در ساخت ورق فلزى است. در صـورت تغييـر

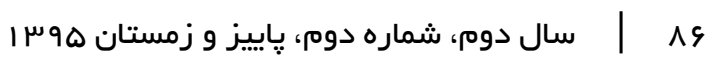


مىرسد در دورهى اسـلامى طلاكـارى بــاويـره در ادوار صفويه، زنديه و قاجاريه رواج داشته و بيشترين كاربرد آن در تزئينات معمارى بوده است. در اين سه دورهى متأخر، طلاكارى روى سنگ، غالباً به دو صورت طلاجِيسانى بـر سطح سنگ و تزئينات برجستهى مطلا (لايسهجينسى) بـر

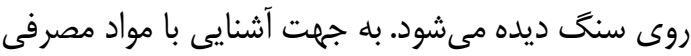
در اجراى اين تزئينات در دورمى صفويه، نمونهاى متعلق

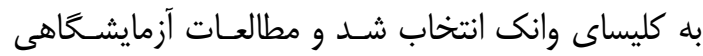
انجام كَرفت. بررسىها نشان داد كه از ورق طلا براى اين

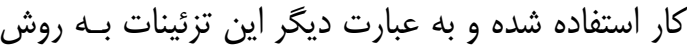

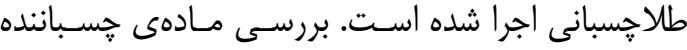

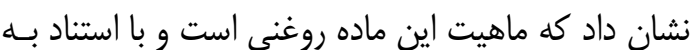
منابع مكتوب، روغنسى كـه در فـن طالاجسـبانى كـاربرد داشته، ممكن است روغن كمان بوده باشد. از آنجا كـه از يك مادهى روغنى استفاده شده است، بايد كَفت تكنيـى رونى طلاكارى اين كتيبهها "طالاكارى روغنى" است. هرجنـــ با بررسى يك نمونه نمىتوان در مورد اجراى اين تزئينات

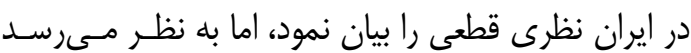
طلاجسبانى به روش طلاكارى روغنسى روشى سـاده و

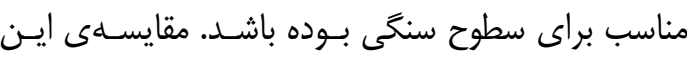

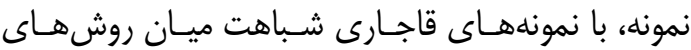

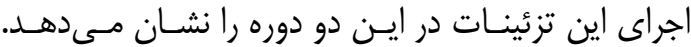

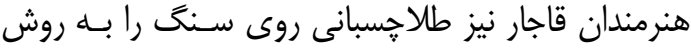

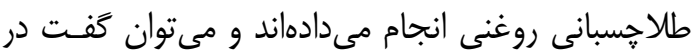
اجراى اين تزئينـات وامدار هنرمنــدان صـفوى بـودهانـــــان. بىشك بررسى نمونههاى متعدد مربوط به ادوار مختلـف ترن به جهت تكميل اطلاعات در اين زمينه و ثبت ويزگكى بهاى

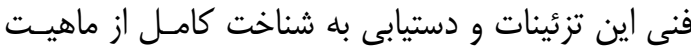
اين فن در ايران، امرى ضرورى است.

\section{سياسگزارى}

نغارنده بر خود لازم مى داند بـــينوسـيله از راهنمـايىهـاى

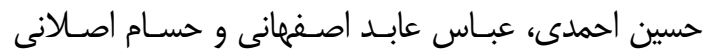

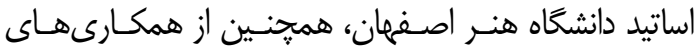

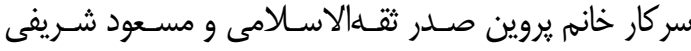
مديران سابق مجموعلى كاخ كلستان، عبدالحميـــ رضـايى

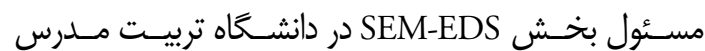

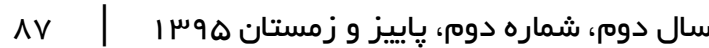

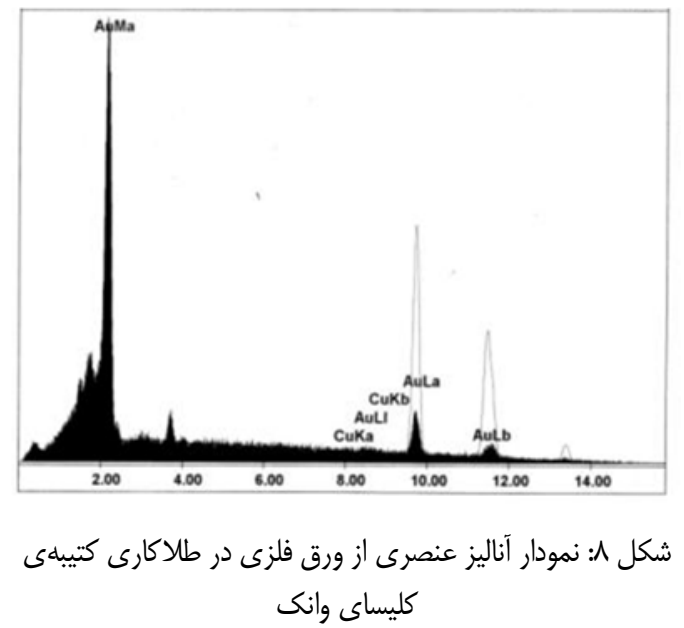

Fig. 8: Elemental analysis diagram of metal leaf in the gilded inscription- Vank Cathedral

جدول r: جدول مربوط به مقادير عناصر فلزى در ورق طلا Table 2: Concentration of metallic elements in gold leaf

\begin{tabular}{|l|c|c|}
\hline Element & Wt $\%$ & At $\%$ \\
\hline $\mathrm{Ca}$ & 1.39 & 6.39 \\
\hline $\mathrm{Cu}$ & 0.77 & 2.23 \\
\hline $\mathrm{Au}$ & 97.84 & 91.38 \\
\hline Total & 100.00 & 100.00 \\
\hline
\end{tabular}

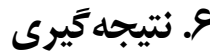

طبق مطالعات انجـام شـده و نمونسهـهـاى تـا بــه امـروز شناسايى شده، قدمت فن طلاكارى روى سنگ در ايران

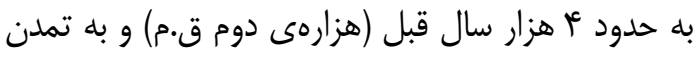

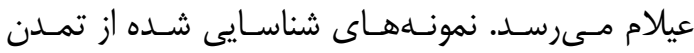

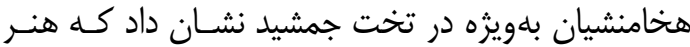

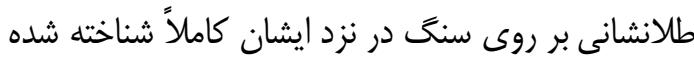
و داراى جايكاه بوده و در زينتبخشى به اشياء و تزئينات معمارى كاربرد داشته است. در فاصلهى آغاز اسلام تا آغاز دورهى صفوى با وجود بررسى هاى بسيار، نمونهاى از اين تزئينات مشاهده نشد و همان كَونه كه بيان شد اين مسئله نمى تواند جندان متأثر از دستورات دين اسلام مبنى بر منع استفاده از طلا بوده باشد. احتمال قوىتر در معدود بـودن

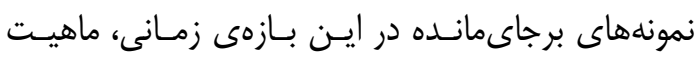

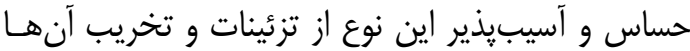
بلهرور زمان بوده است. همجنين اين امكـان وجـود دارد

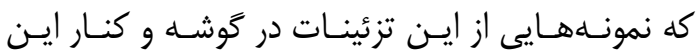

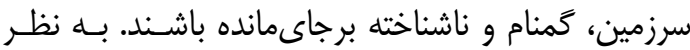


انشاندن جواهر بر (Dehkhoda, 1998, p. 6634, V. 5)

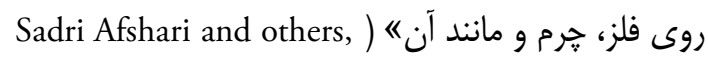
(1990, p. 293 سطح سنگ است.

ז. اين عبارت ارمنى، به معناى "اناجى مقدس همخَان است (Haghnazarian, 2006, p. 47).

\section{References}

Aghajani Esfahani, H., \& Javani, A. (2007). Safavid mural paiting in Isfahan. Tehran: Farhangestan Honar. [in Persian]

Ahmadi, H, Abed-Esfahani, A., \& Mohtasham, A. (2011). Technology of gilding on stone in Tehran golestan palace. Maremat asar $v$ baft-haie tarikhi farhangi, 1(1), 1-14. [in Persian]

Amena Pergij monastery. (2012). Caliphate of Isfahan $\&$ west Iran Armenians: Http//www.vank.ir (access date: 2015/01/05). [in Persian]

Amid, H. (1976). Amid persian dictionary. Tehran: Amir Kabir. [in Persian]

Barzin, Parvin. (1966). Ganjine Hall of national museum of Iran. Honar v mardom, 4 (44), 21-30. [in Persian]

Borges, R., Tissot, I., Seruya, A. I., Silva, C., Rui, J., Fragoso, S., ... \& Pais, A. (2008). Gilding and silvering Surface decoration techniques, and copper provenance studies of the tomb of $\mathrm{D}$. Afonso of Portugal (15th century). X-Ray Spectrometry, 37(4), 338-345.

Burden, E. (2012). Illustrated dictionary of architecture. McGraw Hill Professional.

Caliphate of Isfahan \& west Iran Armenians: Http//www.vank.ir (access date: 2014/11/05). [in Persian] Dehkhoda, A.A. (1998). Dehkhoda dictionary. Vol. 9 \& 10. Tehran: Tehran University.

Derrick, M. R., Stulik, D., \& Landry, J. M. (2000). Infrared spectroscopy in conservation science. Getty Publications. Duran, A., Perez-Rodriguez, J. L., \& de Haro, M. J. (2009). Study of the gilding technique used in polychromed stones and ceramics by dedicated laboratory-made micro Xray diffraction and Complementary techniques. Analytical and bioanalytical chemistry, 394(6), 1671-1677.

Edwards, C. (2000). Encyclopedia of furniture materials, trades and techniques. Ashgate.

Ehsani, M.T. (2003). Parsian covers and pen boxes and miniature. V. 2. Second publication. Tehran: Amir Kabir. [in Persian]

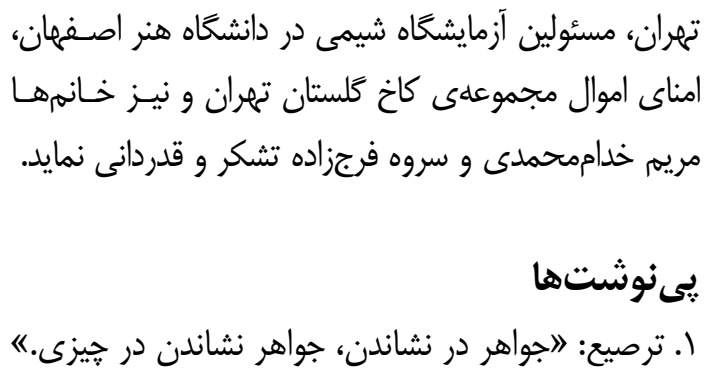

Elam. (2009). Louvre museum official website. http://www. Louvre.fr/llv/ recherché/ resultuts / Elam. (Accessed 2010/2/25).

Faraj zadeh, F. (2011). Technology, pathology and conservation and restoration plan of Qajarian painted description in Taqe bostan, (Unpublished master's thesis). Art university of Isfahan. [in Persian]

Gettens, R. J., \& Stout, G. L. (1942). Painting materials: a short encyclopaedia. Courier Corporation.

Habashi, F. (2005). Gold - An historical introduction. Developments in Mineral Processing, Vol 15, xxvxlvii. [in Persian]

Haghnazarian. A. (2006). New Jolfa Armenians churches in Isfahan. Tehran: Farhangestane Honar. [in Armenian] Harris, C. M. (2006). Dictionary of Architecture and Construction. McGrawHill.

Hatchfield, P., \& Newman, R. (1991). Ancient Egyptian gilding methods, Sound View Press, 27-47.

Holakouie, P. (2008). Technology and pathology of pastiglia ornaments safavid monuments in Isfahan. (Unpublished master's thesis). Art university of Isfahan. [in Persian]

Lins, A. (2000). Gilding techniques of the renaissance and after. In Gilded metals: history technology and Conseration, Archetype, 241-265.

Loon, M. N. V. (1962). A Lion Bowl from Hasanlu. Expedition, 4(4), 14. July 1962 Web. 26 Mar 2017.

Moein, M. (2001). Moein persian dictionary. Vol. 1 $\& 2$. Tehran: Sorayesh. [in Persian]

Mohtasham, A. (2010). Technology, pathology and conservation plan for pastiglia ornaments on stone in

Qajar period. (Unpublished master's thesis). Art university of Isfahan. [in Persian]

Mojarrad Takestani, A. (1993). Guidance of painting and book designing in Iran. Qom: Astaneie moqaddase Hazrate Maesoumeh. [in Persian]

Mokhtari, R., \& Esmaeili, A. R. (2006). Isfahan art through the eyes of travelers. Tehran: Farhangestane

سال دوم، شماره دوم، ״ياييز و زمستان هوس I

$\wedge \wedge$ 
Honar. [in Persian]

Monshi Qomi, Qazi A. (1987). Golestane honar. In A. Soheily-Khansari, (Ed.). Tehran: Manuochehri library. [in Persian]

Mousavi-Asl, S. (2010). Conservation and restoration of painting on stone in Aieneh portico of Chehelsotoun palace. (Unpublished master's thesis). Art university of Isfahan. [in Persian]

Nemati-Babaylou, A., Azadi. M., \& Najafi, F. (2013). Technology of Lāck and Roghan in Persian book designing. Pazhuheshe Honar, 4, 149154. [in Persian]

Nemati-Babaylou, A., Azadi. M., Najafi, F., \& Mohammadi, M. (2016). Kaman Oil; Imitation, Innovation or Localisation? The First International Conference on Arts and Crafts in Iranian-Islamic Culture and Civilization: Declining arts in focus. [in Persian]

Oddy, W. A. (1981). Gilding through the ages: an outline history of the process in the Old World. Gold bulletin, 14(2), 75-79.

Oddy, W. A. (2000). A history of gilding with particular reference to statuary. In Gilded metals: history technology and conseration, Archetype, 1-19.

Pope, A. U., Ackerman, P., \& Besterman, T. (1964). A survey of Persian art from prehistoric times to the present: Arthur Upham Pope, editor; Phillis Ackerman, assistant editor (Vol. 6). Oxford University Press.

Price, Christin. (1976). The story of Moslem art. (M. rajab-nia, Trans.). Tehran: Amir Kabir. [in Persian] (Original work published 1964).

Reiazi, M. R. (1996). Pictorial dictionary of Iranian art. Tehran: Al-zahra University. [in Persian]

Sadri-Afshari, Gh., Hokmi, N., \& Hokmi, N. (1990). Dictionary of today Persian language. Tehran: Kalameh. [in Persian]

Sayed Sadr, S.A. (2009). Encyclopedia of painting. Tehran: Simaiedanesh. [in Persian]

Shayesteh-far, M. (2008). Description decoration of Vakil mosque in Shiraz. Ketabe mahe Honar, 4(120), 64-75. [in Persian]

Stodulski, L., Farrell, E., \& Newman, R. (1984). Identification of ancient Persian pigments from Persepolis and Pasargadae. Studies in Conservation, 29(3), 143-154. 